\title{
Immatures of Heterispa vinula (Erichson) and Physocoryna scabra Guérin-Méneville (Coleoptera, Chrysomelidae, Cassidinae, Chalepini)
}

\author{
Sônia A. Casari ${ }^{1,3}$ \& Édson P. Teixeira ${ }^{2}$
}

\begin{abstract}
${ }^{1}$ Museu de Zoologia, Universidade de São Paulo. Caixa Postal 42594, 04299-970 São Paulo-SP, Brazil. E-mail: casari@usp.br ${ }^{2}$ Instituto Agronômico de Campinas. Caixa Postal 28, 13020-902 Campinas-SP, Brazil. E-mail: edson@iac.sp.gov.br. ${ }^{3}$ CNPq. fellowship.
\end{abstract}

\begin{abstract}
Resumo. Imaturos de Heterispa vinula (Erichson) e Physocoryna scabra Guérin (Coleoptera, Chrysomelidae, Cassidinae, Chalepini). Larva e pupa de Heterispa vinula (Erichson, 1847) e larva de Physocorina scabra Guérin-Méneville, 1844 são descritas e ilustradas. O material de H. vinula foi coletado em Sida carpinifolia (L.f.) K. Schum (Malvaceae) em São Paulo (Ipiranga e Mooca), e P. scabra em acerola (Malpighia glabra L.) (Malpighiacea) em Cruz das Almas, Bahia. Os imaturos do gênero Physocoryna são descritos pela primeira vez.

Palavras-Chave. Heterispa; Malpighia; minadores; Physocoryna; Sida.

Abstract. Larva and pupa of Heterispa vinula (Erichson, 1847) and larva of Physocorina scabra Guérin-Méneville, 1844 are described and illustrated. The material of $H$. vinula was collected feeding on Sida carpinifolia (L.f.) K. Schum (Malvaceae) in the city of São Paulo (Ipiranga and Mooca districts), and of P. scabra on acerola (Malpighia glabra L.) (Malpighiacea) in Cruz das Almas, Bahia. Larvae of genus Physocorina are described for the first time.
\end{abstract}

KeYwords. Heterispa; Malpighia; miners; Physocoryna; Sida.

The larvae of Chalepini are particularly characterized by a body which is flattened and slightly sclerotized; median endocarina located between frontal arms; epicranial stem absent; maxillary palpi 1- or 2-segmented; legs 4-segmented or fewer; abdominal spiracle 8 dorsally placed. They are leaf miners (LAWSON 1991).

Larvae of this subfamily are poorly known. The genus Heterispa Chapuis, 1875 includes five species, and up to now, only immatures of $H$. costipennis (Boheman,1859) were described. The genus Physocoryna Guérin-Méneville, 1844 includes three species and the larvae are unknown yet. We describe here, larva and pupa of Heterispa vinula (Erichson, 1847) and larva of Physocoryna scabra Guérin-Méneville, 1844.

\section{Heterispa vinula (Erichson, 1847)}

(Figs. 1-26, 45)

Young larva. Length: $1.4-4.0 \mathrm{~mm}$. Elongate (Fig. 1), flat with abdominal lateral projection. Integument slightly sclerotized, granulose especially laterally (Fig. 2); cream with head and pronotum yellow. Abdominal segments 1-8 with one well developed projection each side, decreasing in size apically and one dorsolateral anular spiracle. Meso- and metanotum and abdominal segments 1-8 with transversal median band of microspines (Fig. 6), absent ventrally.

Head (Figs. 10,11) prognathous, narrower than prothorax and partially retracted; epicranial stem absent; median endocarina well developed, extending between frontal arms; frontal arms V-shaped. Six stemmata each side (Figs 9-11): three lateral, one laterodorsal and two ventral (one near antennal base and one at middle of hypostoma). Frons bearing 6 short setae each side of endocarina (except 4 near stemata). Each side epicranial plate bearing 6 setae near middle. Frontoclypeal suture incomplete. Clypeus transverse, each side with three setae. Labrum (Fig. 12) free, transverse, subtrapezoidal, each side with three pores and one short setae. Epipharynx (Fig. 13) bearing, near anterior margin, 4 long stout setae in transverse row near fore angle, 5 shorter stout setae each side of median sclerotization and a tuft between these two rows; a median raised bifid and sclerotized area on basal 2/3, each side with two large sensorial pores and a short seta, disposed in inclined row, and a plate of pores. Antennae (Figs. 16, 17) 3-segmented; basal segment transverse with one sensorial pore laterodorsal and two ventral near middle; median segment elongate with one subapical short seta dorsal and one ventral, and at apex, a very long membranous sensorium at internal half and a ventral short wide seta near middle; distal segment reduced, located at external distal half of median segment, slightly longer than sensorial cone and bearing at apex, 6 setae (2 longer, 2 stout shorter and 2 median size). Gula absent. Mandibles (Figs. 14, 15) elongate, apex 3-toothed; with one setae and 3 pores laterally; penicillus absent. Maxillolabial complex (Fig.19) as long as head. Maxillae: cardo indistinguishable; mala (Figs. $18,19)$ elongate, lobe-like, bearing ventrally 4 long and stout setae at apex and 4 shorter disposed in row parallel internal margin; dorsally with 4 long and wide setae near apex and microsetae distributed at area below mala and near palpifer; ventrally with one seta and one pore below palpifer; palpifer with one seta. Maxillary palpi 2-segmented; basal segment elongate, ventrally with one seta and one pore; distal segment narrower and elongate with laterointernal seta near apex and 

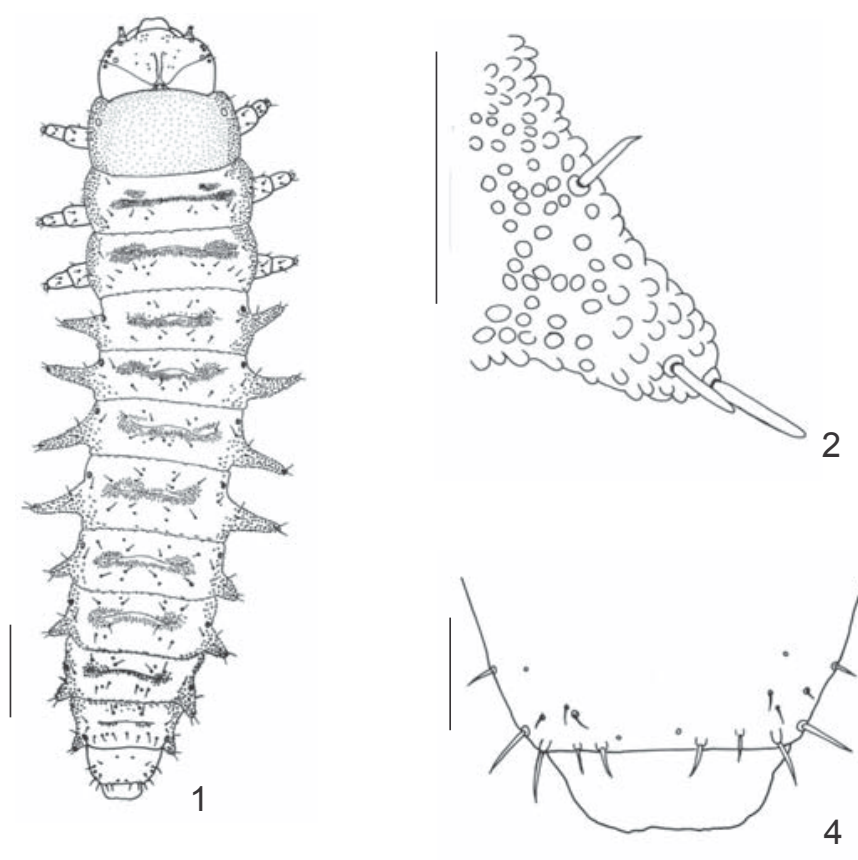

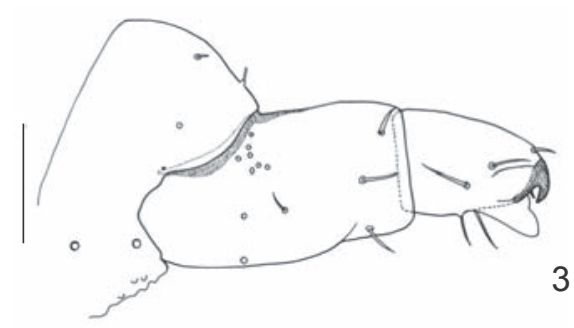

2

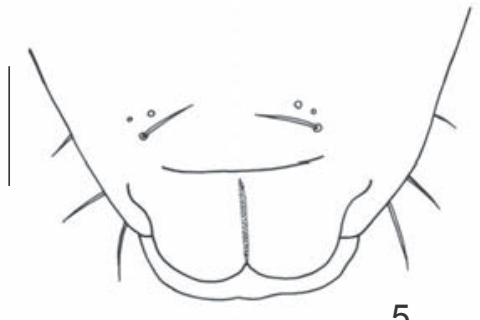

5

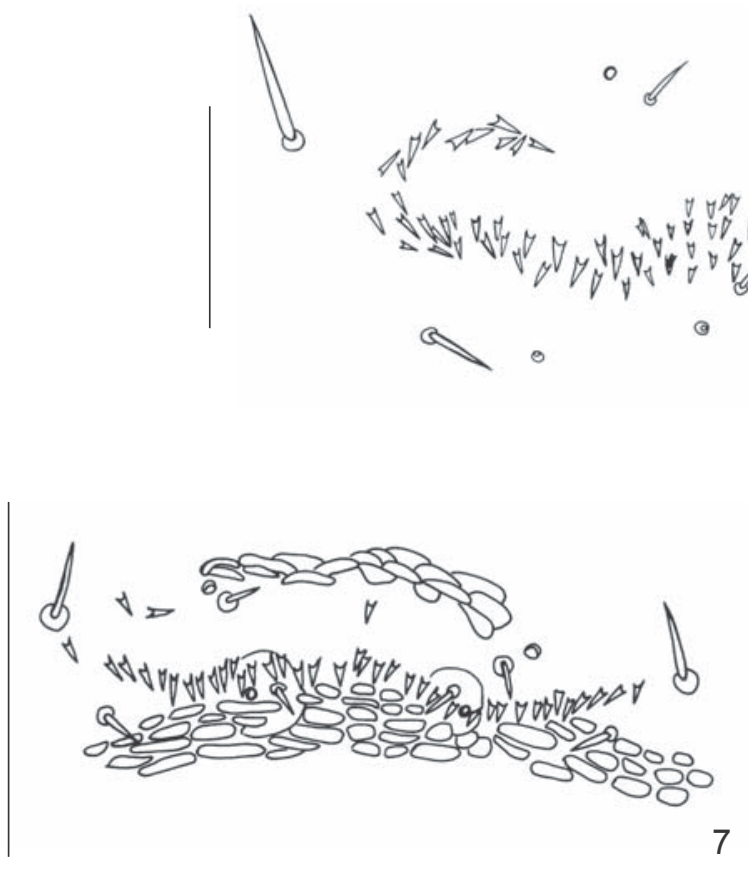
7
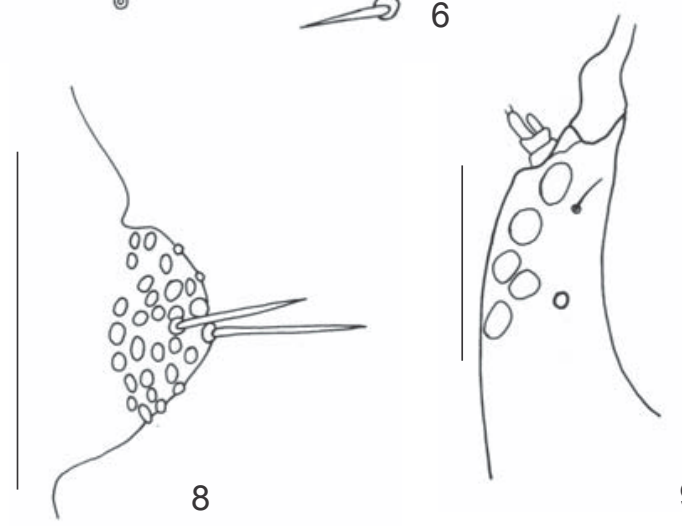

Figs. 1-9. Heterispa vinula (Erichson, 1847). Larva: 1, dorsal; 2, lateral projection of segment 6; 3, metathoracic leg (internal); 4, 5, abdominal apex (dorsal, ventral); 6, $1^{\text {st }}$ abdominal tergite. First instar larva: 7, $1^{\text {st }}$ abdominal tergite; 8, lateral projection of segment 2; 9, head (lateral). Bars $=1 \mathrm{~mm}$ except fig. $1=0.5 \mathrm{~mm}$.

10 small sensorial cones. Stipes elongate bearing 8 short setae. Labium: lígula well developed and rounded, marginate by fringe of short setae; ventrally bearing 4 sensorial pores and dorsally clothed with short and fine setae; labial palpi one-segmented, elongated, bearing at apex 7 small sensorial cones; palpiger with one short seta; postmentum elongate bearing 2 sensorial pores near anterior margin.
Pronotum transverse, longer than meso- or metanotum; meso- and metanotum band-like; mesosternum bearing lateroanteriorly a pair of annular spiracular openings.

Legs (Fig. 3) long and 4-segmented: coxa, wide with short setae, femur elongate with setae moderately long, tibia elongate with long setae and bearing two distal membranous lobes at tarsungulus base; tarsungulus sclerotized, short and wide, 

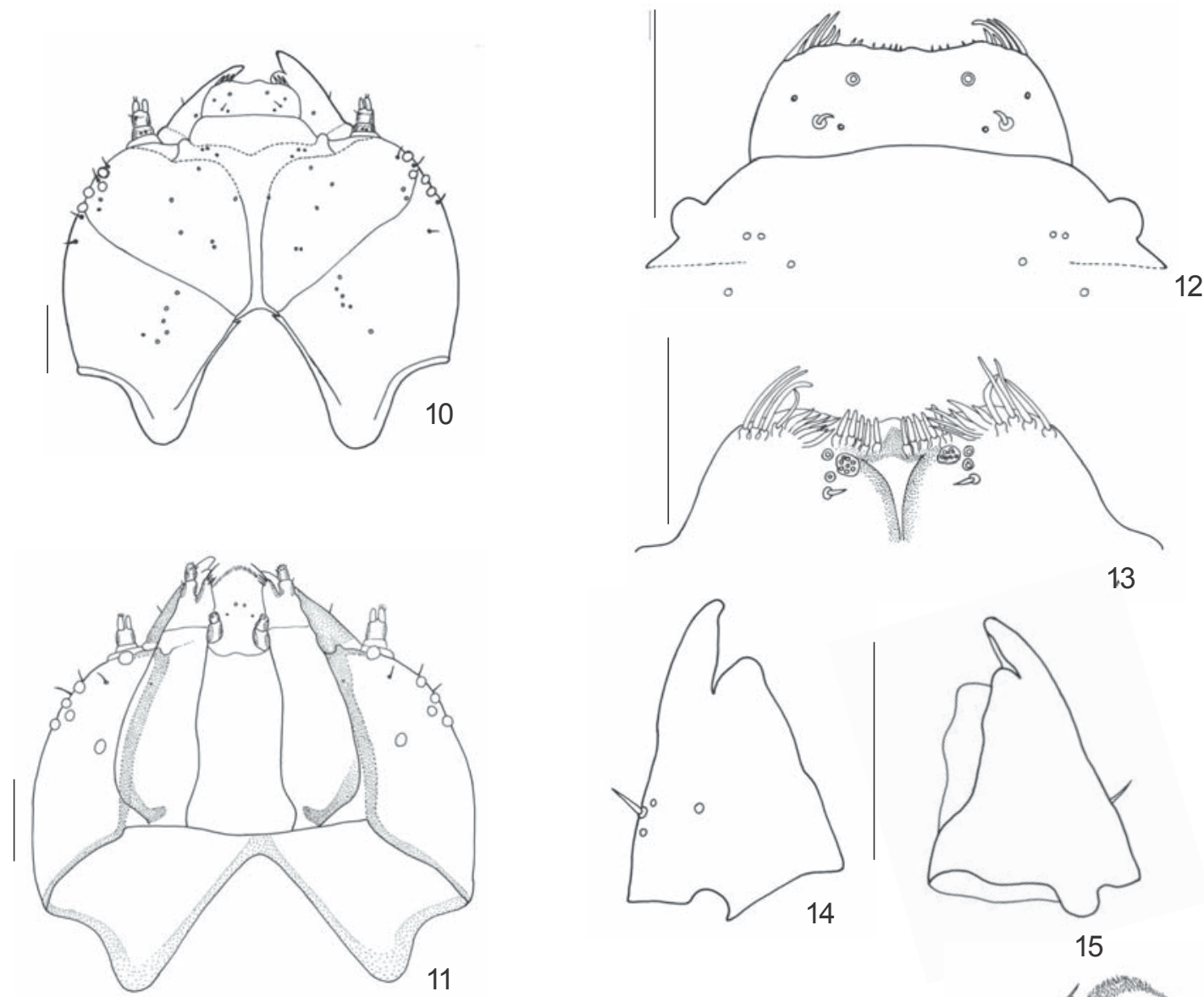

13
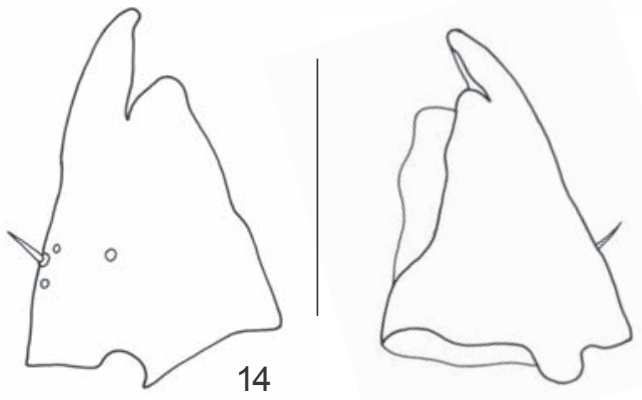

15

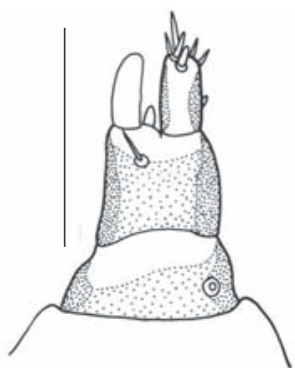

16

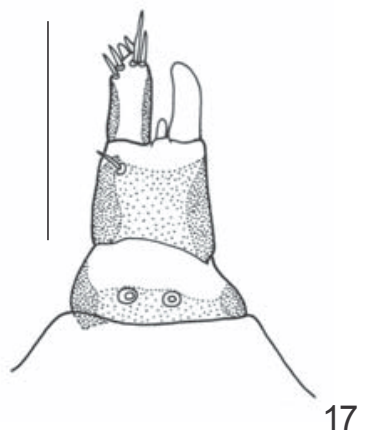

17

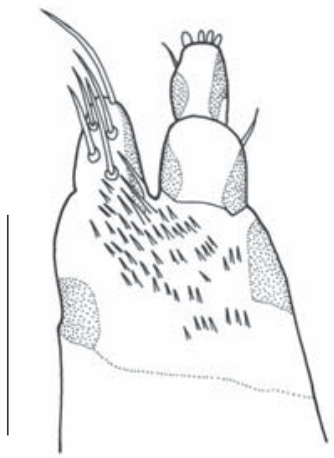

18

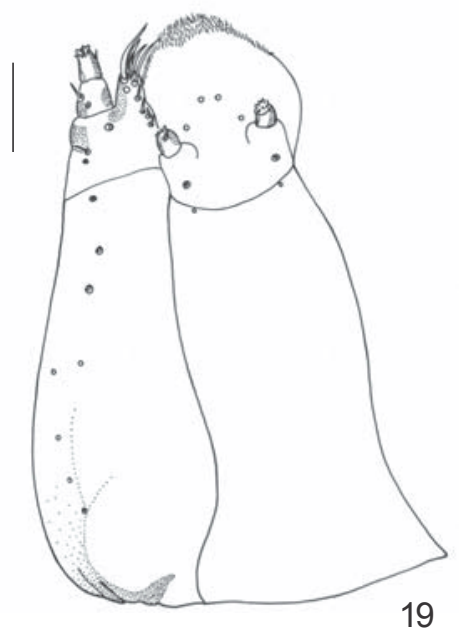

Figs. 10-19. Heterispa vinula (Erichson, 1847). Larva: 10, 11, head (dorsal, ventral); 12, clypeus and labrum; 13, epipharynx; 14, 15, mandible (dorsal, ventral); 16, 17, antenna (dorsal, ventral); 18, apex of maxilla (dorsal); 19, maxilla and labium (ventral). Bars $=1 \mathrm{~mm}$, except figs. 16$19=0.5 \mathrm{~mm}$.

bearing one lateroexternal seta.

Abdominal segments 1-8 band-like with lateral projection and a pair of dorsolateral annular spiracular openings; segment 9 narrower, with distal angle rounded and marginate by setae; segment 10 (Figs. 4, 5) reduced and bilobed ventrally.

First instar larva. Length: 1.0-1.2 mm. Similar to young larva, differing especially by presence, on tergites, of tranverse band of sclerotized plates, absent in more mature larvae, and band of microspines narrower (Fig. 7), lateral projections of abdomen shorter (Fig. 8) and ventral stemmata shorter (Fig. 9) than mature larvae.

Pupa. Length: 6.0-6.5 mm. White with very long brown 

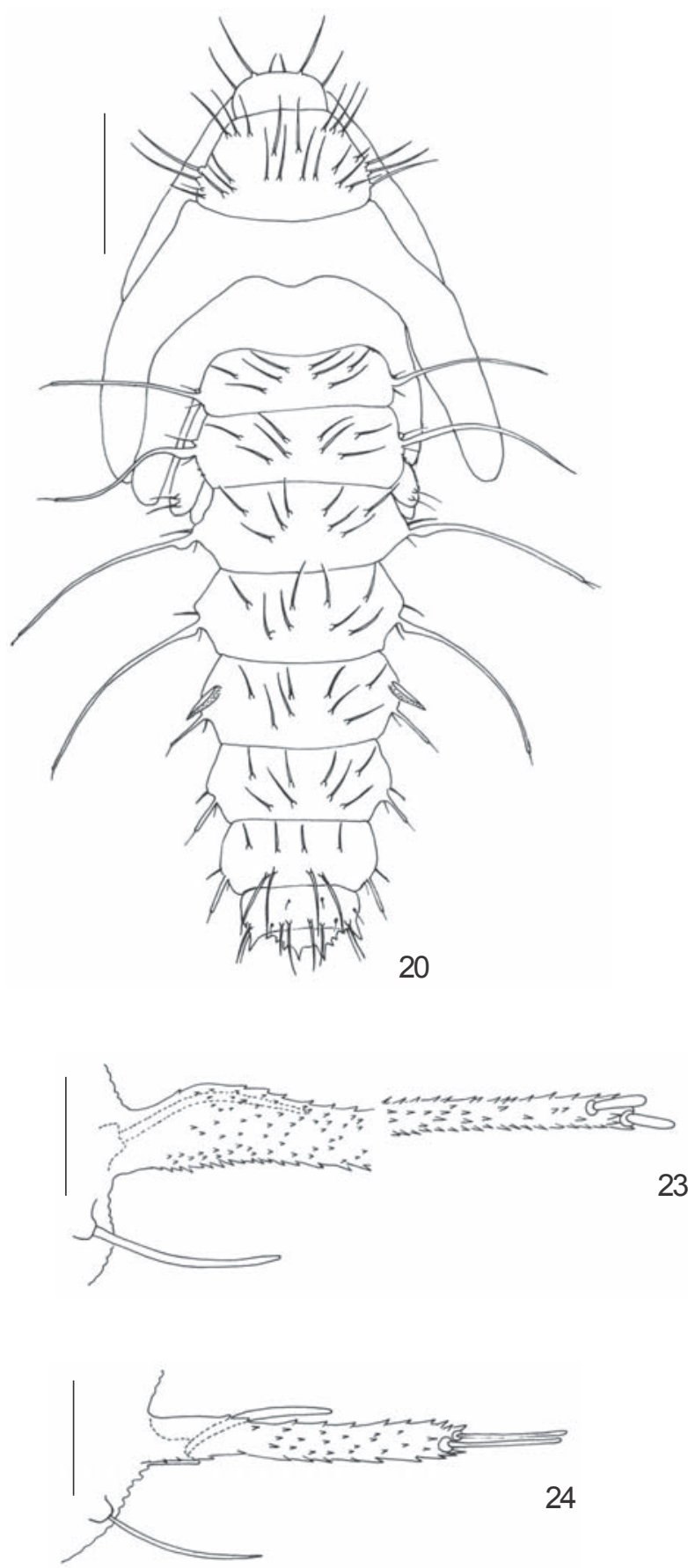
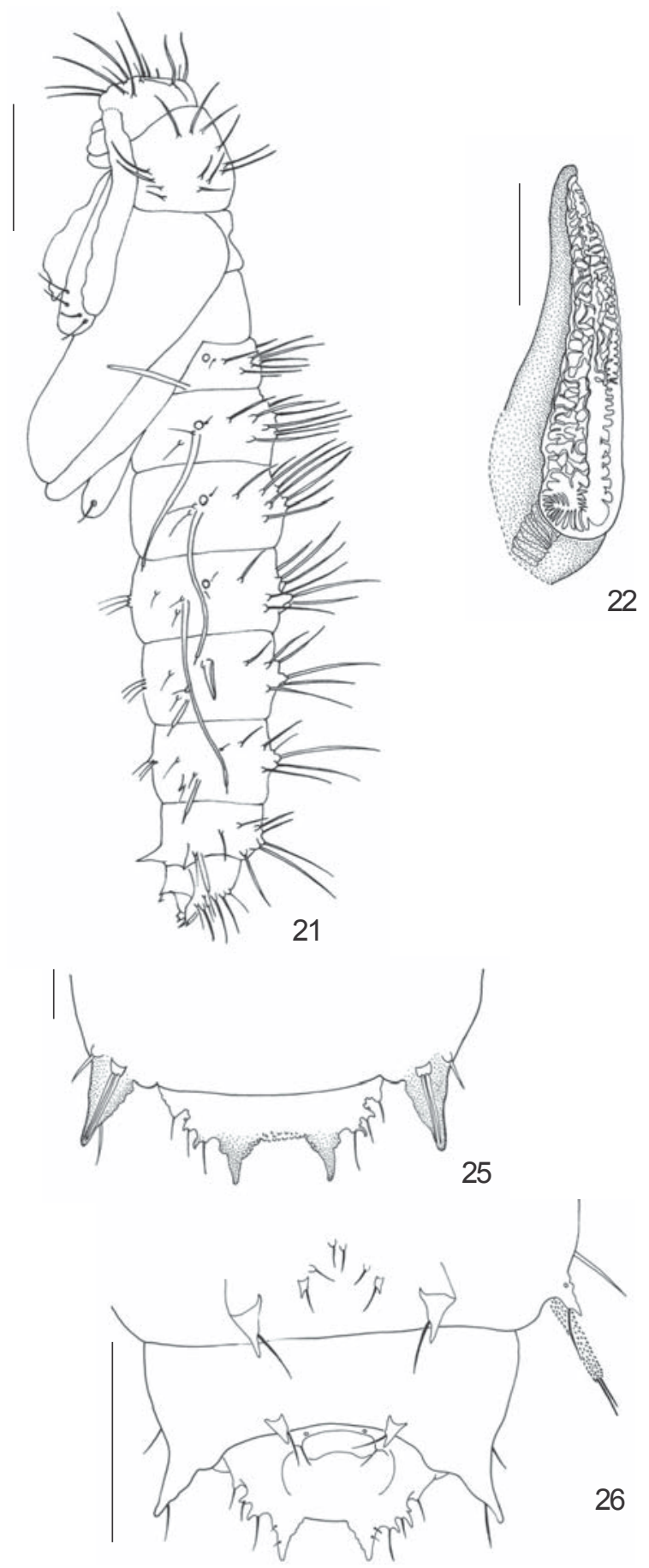

Figs. 20-25. Heterispa vinula (Erichson, 1847). Pupa: 20, dorsal; 21, lateral; 22, spiracle 5; 23, 24, lateral projection of abdomen (dorsal) (segments 4, 6); 25, 26 apex of abdomen (dorsal, ventral). Bars $=1 \mathrm{~mm}$.

setae inserted in small lobes; abdominal segments 1-7 with long microspined lateral prolongations (Figs. 23, 24) of varied sizes. Head partially visible from above with 8 pair of long setae; pronotum with 13 pairs. Abdominal segments 1-7 bearing 4 pairs of long dorsal setae near middle, each side with one very long prolongation (shorter on segments 5-7) with two short setae at apex and one dorsal and one ventral seta at base; segment 5 with laterodorsal sclerotized short prolongation with one spiracular opening (Fig. 22) each side; segments 6-7 bearing a tooth ventrally at base of lateral prolongation; segment 8 with one sclerotized tooth each distal angle and 7 pairs of setae (one pair inserted at same lobe near tooth); segment 9 (Fig. 25) marginate by sclerotized teeth, distal pair longer. Abdominal segments 1-4 bearing laterally openings 

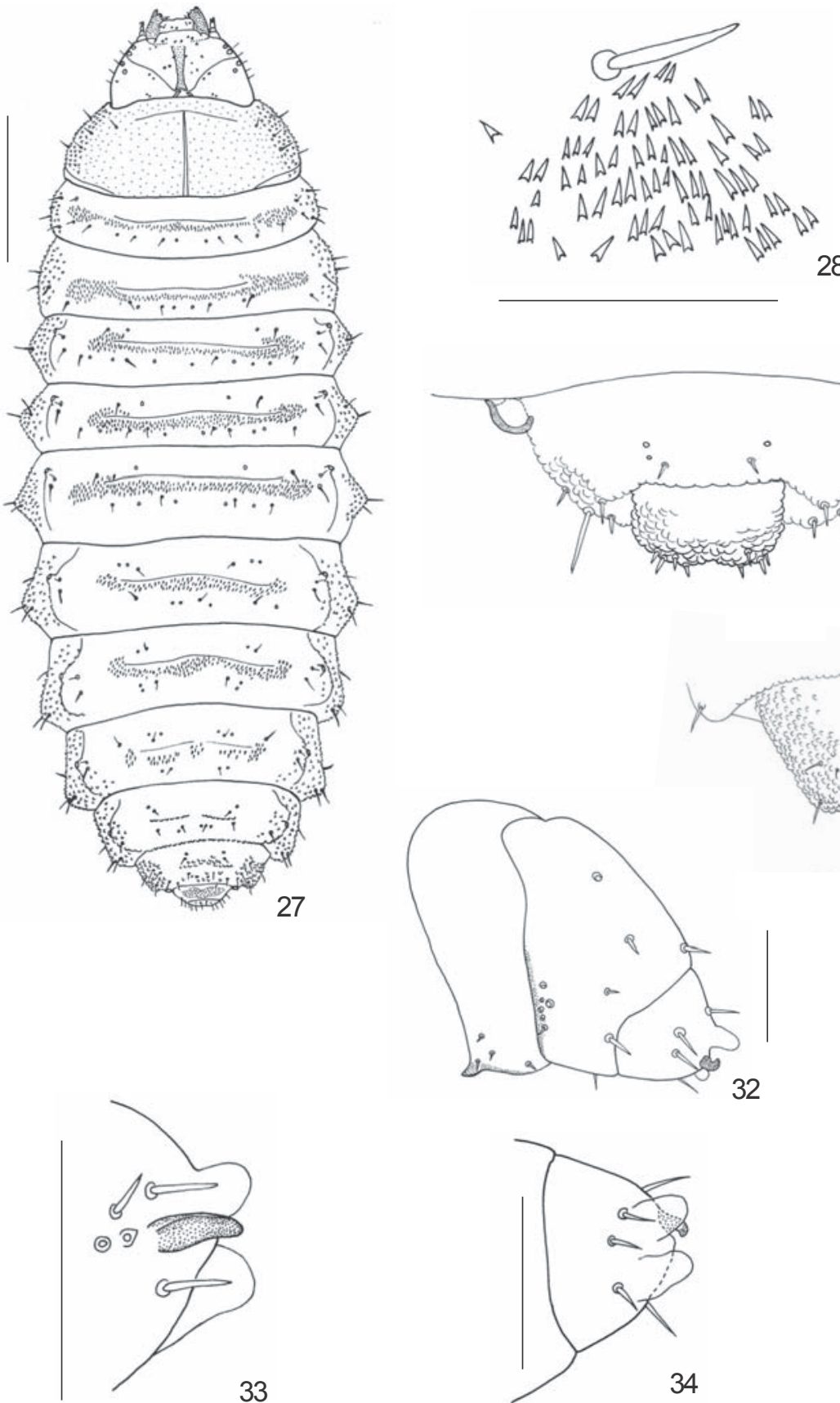

28

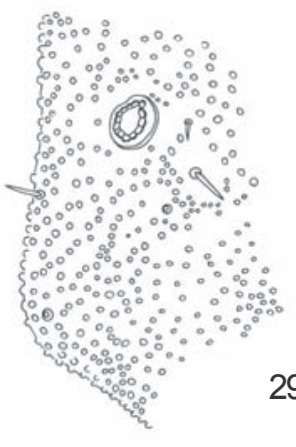

29
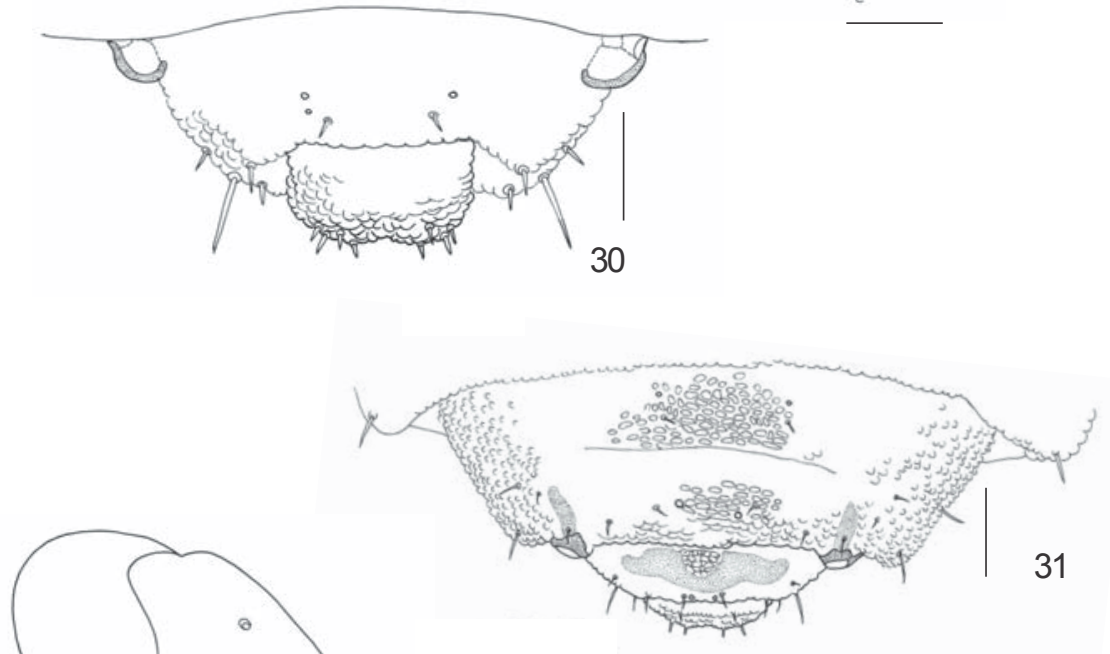

33

34

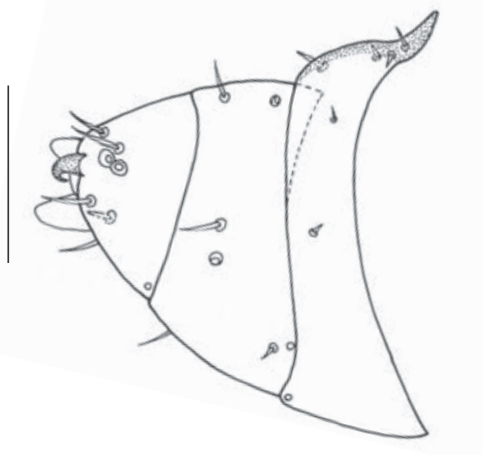

35

Figs. 27-35. Physocoryna scabra Guérin-Méneville, 1844. Larva: 27, dorsal; 28, detail of microsetae of tergites; 29, lateral projection of segment 6; 30, 31, apex of abdomen (ventral, dorsal); 32, 35, legs (mesothoracic, prothorarcic); 33, 34, tasungulus and apex of tibia (external, internal). Bars $=1 \mathrm{~mm}$

of annular spiracles. Sternites 4-6 bearing at middle 3 pair of setae; 6-8 with one pair of sclerotized teeth near middle; 7 with 3 pairs of setae near middle, one inserted in sclerotized prolongation.

Material examined. BRAZIL. São Paulo: São Paulo (Ipiranga), 15.XII.1998, S. Ide col., 5 larvae (young), 2 pupae, 6 adults; I.2002, S. Ide col., 4 larvae mining two leaves; (Mooca), 10.II.2003, C. Campaner col., 5 adults. All material at Museu de Zoologia, Universidade de São Paulo (MZSP).
Remarks.The only species of Heterispa with known immatures forms is H. costipennis (Boheman,1859), described by BRÈTHES (1902). He presented the description of egg, larva, pupa and mined leaf. According to him, the eggs are put in groups of 4 or 5 , under the leaves of Sida rhombifolia L. The first egg is put basally on one vein and they are fixed with an adhesive and corrosive substance, that keeps the eggs stuck to the cuticle. The corrosion of the cuticle may allow the larva 

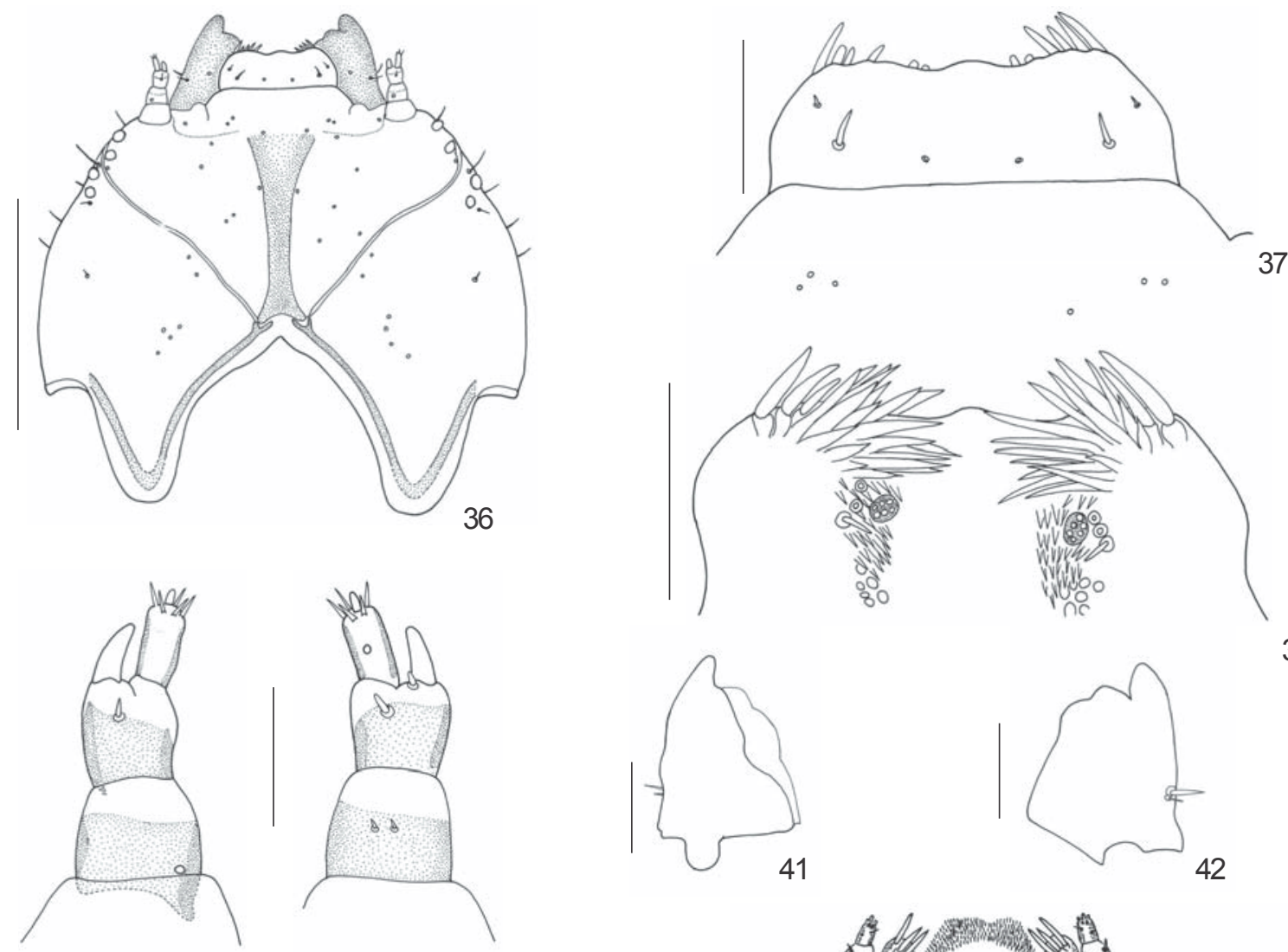

39
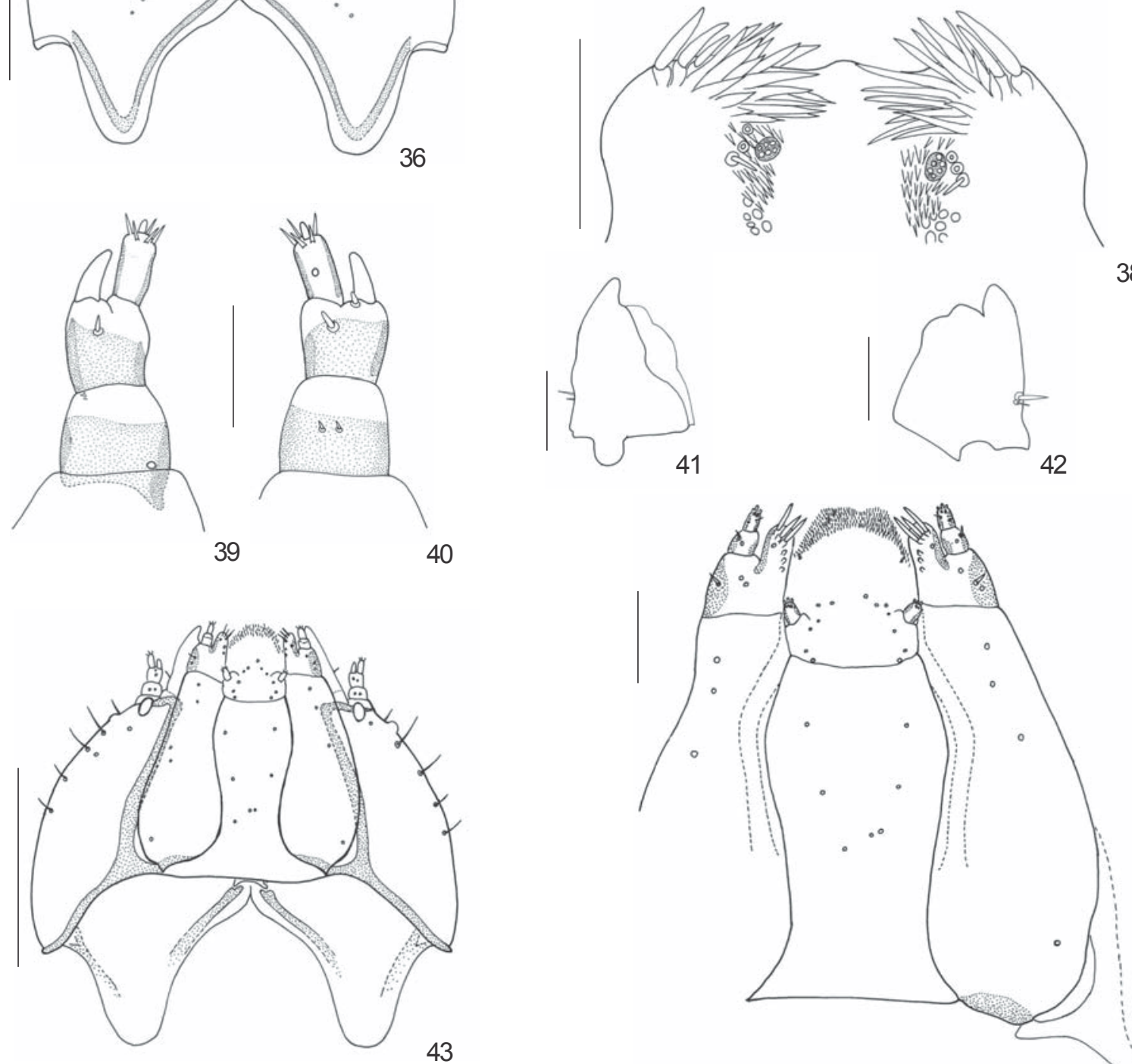

38

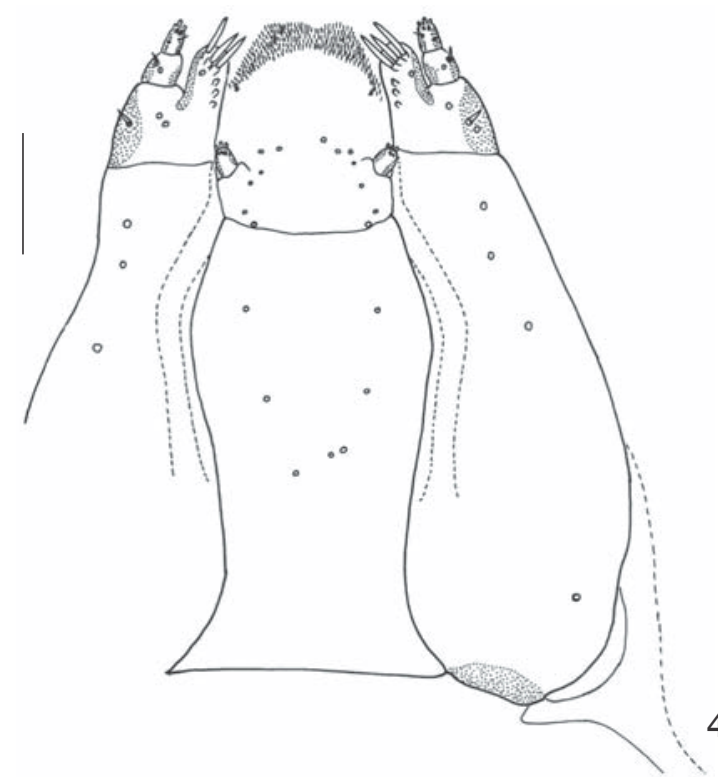

Figs. 36-44. Physocoryna scabra Guérin-Méneville, 1844. Larva: 36, 42, head (dorsal, ventral); 37, clypeus and labrum; 38, epipharynx; 39, 40, antenna (dorsal, ventral); 41, 42, mandible (ventral, dorsal); 44, maxillae and labium (ventral). Bars $=1 \mathrm{~mm}$, except $39,40=0.5 \mathrm{~mm}$.

to get into the parenchyma just after the egg ecloses.

Besides Sida rhombifolia (Malvaceae), STAINES (1996) cited as food plants of Heterispa vinula: Triumfetta josefina Polak. (Tiliaceae), Guazuma ulmifolia L. (Sterculiaceae) and Infigofera (Fabaceae).

Larvae and pupae of $H$. vinula were collected mining Sida carpinifolia (L.f.) K. Schum, while the adults were on the leaves, some of them in copula.

Comparing the larva and pupa of $H$. vinula with the description of $H$. costipennis, it is possible to observe only very slight differences, these being the lateral prolongations of abdominal segments of pupa shorter in the latter, being only those of $4^{\text {th }}$ segment as long as in $H$. vinula. 

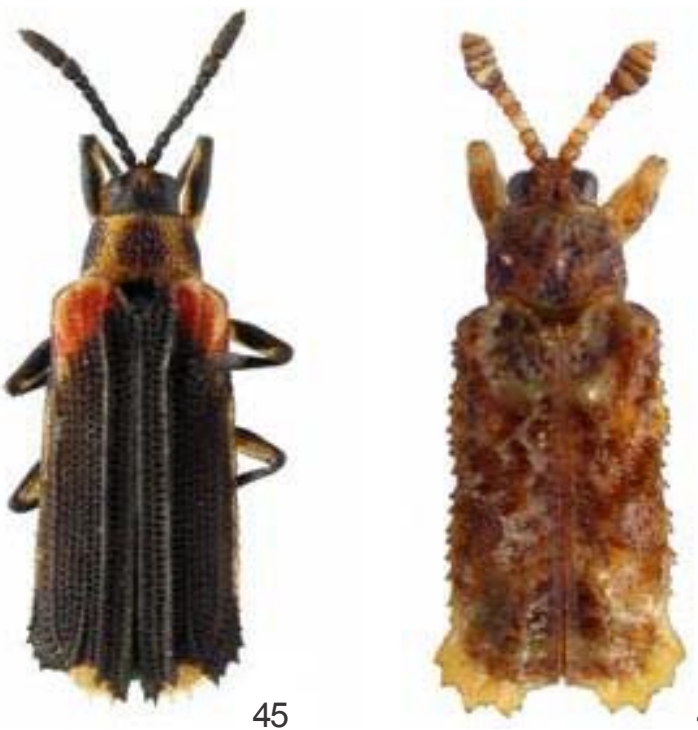

46
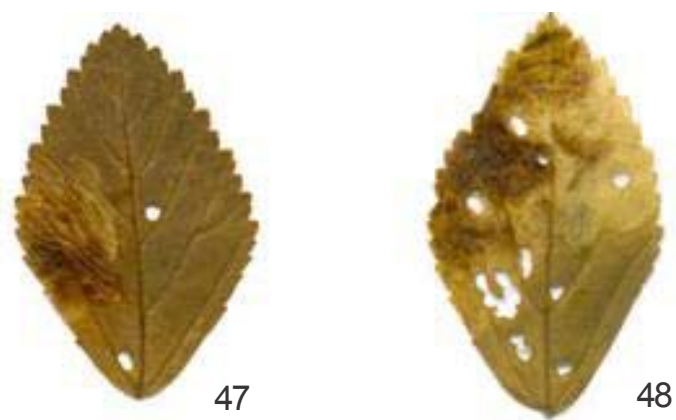

Figs. 45-48. 45, habitus, Heterispa vinula (Erichson, 1847); 46, habitus, Physocoryna scabra Guérin, 1844; 47, 48, leaf of Sida (mined).

\section{Physocoryna scabra Guérin-Méneville, 1844}

(Figs. 27-44, 46)

Mature larva. Length: 6-7 mm. Elongate, wide and flattened (Fig. 27). Integument slightly sclerotized, sparsely granulose (Fig. 29), especially laterally; cream with head, wide plate on pronotum and prosternum yellow, and spiracular openings and transverse plate on tergite 9, brown. Meso- and metathorax and abdominal segments 1-6 bearing transverse row of microspines (Fig. 28) dorsal and ventral. Each side of abdominal segments 1-7 with small lateral rounded projections and dorsolateral spiracular openings; segment 8 (Figs. 30-31) with spiracular openings displaced distally near lateral margins; segment 9, transverse, narrower, with dorsal transverse sclerotized plate; segment 10 (Fig. 30) narrowed, reduced and almost totally ventral, in some specimens retracted into 9; anal opening distal. All segments bearing dorsally and ventrally, short setae and sensorial pores.

Head (Figs. 36, 43) prognathous, narrower than prothorax and partially retracted; epicranial stem absent; median endocarina well developed, extending between frontal arms, almost reaching clypeus, bifid at apex; frontal arms V-shaped.
Five stemmata each side: four laterodorsal and one ventral near antennae base. Each side of frons bearing 7 setae plus 3 of clypeal area. Each epicranial plate bearing dorsally 9 setae. Frontoclypeal suture incomplete. Clypeus transverse, each side with three pores near base. Labrum (Fig.37) free, transverse, with anterior margin sinuous; two setae (one very short) each side and 2 sensorial pores at middle near base. Epipharynx (Fig. 38): lateroanteriorly with wide setae forming a tuft-like; each side with two pores and one seta disposed in inclined row and one group of sensorial pores. Antennae (Figs. 39, 40) 3-segmented: basal segment as long as wide, bearing two short ventral setae near middle and one pore laterodorsal; median segment slightly shorter than basal, bearing at apex an elongate membranous sensorium at internal half, one short seta dorsal and one ventral near middle, and one short seta ventral, at base of sensorium; distal segment slightly shorter than median, located at external apical half of median segment, longer than sensorium, bearing a ventral sensorial pore near middle and, at apex, one membranous sensorium surrounded by 5 stout setae. Gula absent. Mandibles (Figs. 41, 42) robust with one well developed tooth at apex, one wide and truncate dorsally and 2 small rounded ventrally; penicillus absent. Maxillolabial complex (Fig. 44) as long as head. Maxillae elongate; cardo indistinguishable; mala elongate, ventrally with 6 stout setae and one sensorial pore, and dorsally, with many stout setae forming a tuft-like. Maxillary palpi 2-segmented; basal segment bearing ventrally one lateroexternal seta and one pore near middle; distal segment bearing ventrally, a short seta near internal margin and one pore near external margin, and at apex, 6 stout short setae; palpifer bearing ventrally, one short seta and one pore near lateroexternal margin and one or 2 (right/left side) pores near middle; stipes elongate bearing 4 short setae. Labium elongate; palpi one-segmented bearing distally 5 stout short setae; ligula well developed, rounded, marginated by band of short setae, with 8 sensorial pores ( 2 very small); prementum slightly sclerotized, bearing 3 sensorial pores each side; postmentum elongate bearing 7 sensorial pores. Hypopharynx densely covered with stout short setae.

Pronotum trapezoidal with lateral margins rounded; mesoand metanotum band-like with lateral margins rounded. A ventral pair of annular spiracle lateroanterior on mesothorax.

Legs (Figs 32, 35) robust, 4-segmented; coxae widely separate at middle; bearing short setae; femur bearing 6 short setae laterointernally near coxa and 5 setae internally; tibia bearing internally 3 moderately long setae and with 2 membranous projections at apex, one each side of tarsungulus; tarsungulus (Figs. 32-35) very small and sclerotized.

Abdominal segments 1-6 band-like, with lateral projection bearing two setae and dorsolateral openings of anular spiracles; segment 8 band-like, narrow, with spiracular openings distally; segment 9 reduced with dorsal transverse sclerotization with 8 setae and two pores near anterior margin; segment 10 narrow, elongate and ventral, with 8 setae at apex; anal opening distal.

Material examined. BRAZIL. Bahia: Cruz das Almas, 11.10.1996, Hosp. Acerola, M. Soglia [Soria ?] col., 6 larvae and 4 adults fixed (MZSP). All material at MZSP. 
Remarks. The larva of Physocoryna scabra GuérinMéneville, 1844 is the first larva known in the genus. It was collected on acerola, Malpighia glabra L. (Malpighiaceae); this is the first record of this host plant for the genus. Staines (2002), cited as host plants of Physocoryna: Canavalia, Cymbosema, Dioclea, Phaseolus (Fabaceae); Stimatophyllum (Malpighiacea).

Acknowledgements. To C. L. Staines (USNM) for identification of Heterispa; Guilherme Ide Marques dos Santos (MZSP), by taking the pictures; the late T.C. Ramos for the identification of Physocorina scabra and Sigrid Luiza Jung Mendaçolli (IAC) by identification of Sida.

\section{REFERENCES}

Brèthes, J. 1902. Métamorphose de 1'Uroplata (Heterispa) costipennis (Boh.) Chap. (Hispidae). Anales del Museo Nacional de Buenos Aires 8: 13-17.

Chapuis, F. 1875. In: Lacordaire, J. T. Histoire naturelle des insectes. Genera des Coléoptères. V. 10. Paris, 455p.

Lawson, F. A. 1991. Chrysomelidae (Chrysomeloidea) (= Cassididae, Cryptocephalidae, Megalopodidae, Sagridae, etc.), p. 568-589, In: F. W. Stehr (ed.). Immature insects. Dubuque, Kendall Hunt Publishing Company, v. 2, 975 p.

Staines, C. L. 1996. The Hispinae (Coleoptera: Chrysomelidae) of Nicaragua. Revista Nicaragüense de Entomologia 37/38: 165.

Staines, C. L. 2002. The new world tribes and genera of hispines (Coleoptera: Chrysomelidae: Cassidinae). Proceedings of the Entomological Society of Washington 104(3): 721-784. 